\title{
Fair enough? Women and Fair Trade
}

\author{
Louise McArdle and Pete Thomas \\ Institute of Research in Organization, Work and Employment (iROWE), \\ Lancashire Business School, University of Central Lancashire, Preston, UK
}

\begin{abstract}
Purpose - This paper aims to consider the impact of Fair Trade on producers with particular reference to women involved in Fair Trade production.

Design/methodology/approach - The paper considers Fair Trade as an alternative to rational economic models of free trade and as a tool for development. A gender and development (GAD) perspective is used to assess whether Fair Trade empowers women in developing nations.

Findings - Fair Trade offers an alternative to free trade within capitalist production and has a positive impact for producers. The impact on gender relations within producer communities is limited although there are benefits for some women involved in Fair Trade production.

Research limitations/implications - The paper is based on secondary data and highlights the need for more focused research, which explores the links between gender, cultural relations and Fair Trade.

Originality/value - Understanding that while Fair Trade is usually considered as a positive developmental tool, its impacts are not homogeneous and are subject to the cultural gender relations that exist in producer communities. The paper highlights the need for a more systematic and longitudinal analysis of the impact of Fair Trade for women.
\end{abstract}

Keywords Fair Trade, Empowerment, Development, Gender

Paper type Literature review

\section{Introduction}

Fair Trade is generally considered as a tool to aid development, with the Fair Trade movement being part of the "new globalisation", reshaping patterns of international trade and the processes of corporate expansion that have historically undermined global ecological and social conditions (Murray and Raynolds, 2007). Traditional patterns of international trade have resulted in inequalities between commodity producers and purchasers to the detriment of producers and it is believed that Fair Trade can tackle this imbalance and, at the same time, offer benefits beyond economic returns in the form of the Fair Trade premium which is invested in community projects such as building schools in producer communities. Amongst the aims of Fair Trade is that of addressing gender inequalities in producer communities and providing opportunities for women. In this paper we assess the evidence on the impact that Fair Trade has had on women in producer communities. Our aim is to understand the extent to which involvement in Fair Trade can make material differences to the lives of women in developing nations and contribute to gendered development processes.

The paper begins by outlining the development of Fair Trade and the main principles embodied in the concept, including those that relate specifically to developing opportunities for women. We then briefly review the literature on development and gender and define the perspective that underpins this paper. The

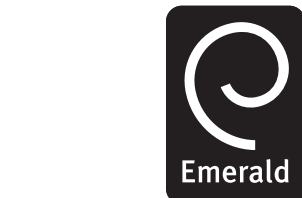

critical perspectives on international business

Vol. 8 No. 4,2012 pp. $277-294$

(C) Emerald Group Publishing Limited 1742-2043

DOI 10.1108/17422041211274165 
CPOIB 8,4

\section{8}

\section{The principles of Fair Trade}

Fair Trade has its roots in the development of networks designed to sell goods produced in communities in developing nations. Alternative trade, as it had previously been known, developed out of charities, often linked to churches, selling goods produced by impoverished and displaced people (Jaffee, 2007). The goods that were sold were principally handicrafts, with the charitable organisations providing a link between producers and markets. From the 1970s and 1980s, alternative trading developed a more secular approach, associated with the Left, in an attempt to generate markets for producers in Socialist countries such as Cuba and Mozambique. Jaffee (2007) argues that such developments were born out of the "trade not aid" approach which attempted to differentiate the alternative approach to trade from paternalistic charitable approaches as well as avoid the inefficiency and corruption of foreign aid by (and to) governments. It has also been suggested that the Fair Trade movement fills the "aid fatigue" void which was apparent in the civil societies of the North, and it has been given an increasingly high profile through popular culture and figures such as Bono from U2 (Goodman, 2004). The development of alternative trade networks (ATOs) can be seen as part of a much wider critique of capitalism and the global economic system (Fridell, 2003; Jaffee, 2007; Lamb, 2008a; Moore, 2004; Murray and Raynolds, 2007; Renard, 2003, 2005). Indeed Renard (2003) aligns the Fair Trade movement with the anti-globalisation movement which emerged out of the protests in Seattle in 1999 and which opposes economic and political globalisation and the resultant social exclusion and ecological destruction.

Fair Trade is a model of trade that operates in stark contrast to the conventional rational economic model of global trade, which aims to maximise return for institutional buyers of commodities through a power imbalance in favour of purchasers. Fair Trade aims to address this power imbalance by offering a "new model of the producer-consumer relationship that connects production and consumption via an innovative supply chain model which distributes its economic benefits more fairly between all stakeholders" (Nicholls, 2005, p. 6; Nicholls and Opal, 2005; see also Raynolds et al., 2007). Traditional business models are seen as fundamentally inequitable so the only way to make them fairer is to set up alternative or parallel trading models (Redfern and Snedker, 2002). In essence, Fair Trade seeks to offer a more even playing field in the arena for international trade, which ensures producers are paid a price which allows them not only to reach a basic standard of living, but also develop their prospects for the future. In this way trade becomes a developmental tool that contributes to international relations in a way that affords disadvantaged producers more control over their own future and a greater return on their work. It is a business relationship in which producers are the primary stakeholders (Moore, 2004). In other words, the overriding imperative of Fair Trade is to return a greater proportion of sales revenue to producers both through direct income and through the social premium. 
To these ends, FINE[1] defines Fair Trade as:

[...] a trading partnership, based on dialogue, transparency and respect, that seeks greater equity in international trade. It contributes to sustainable development by offering better trading conditions to, and securing the rights of marginalised producers and workers especially in the South. Fair Trade organisations (backed by consumers) are engaged actively in supporting producers, awareness raising and in campaigning for changes in the rules and practice of conventional international trade (European Fair Trade Association (EFTA), 2006).

According to Mayoux (2000, emphasis in original), FINE outlines the principles of Fair Trade as being:

- to improve the livelihoods and well-being of producers by improving market access, strengthening producer organisations, paying better prices and providing continuity in the trading relationship;

- to promote development opportunities for disadvantaged producers, especially women and indigenous people and to protect children from exploitation in the production process;

- to raise awareness among consumers of the negative effects on producers of international trade so that they exercise their purchasing power positively;

- to set an example of partnership in trade through dialogue, transparency and respect;

- to campaign for changes in the rules and practice of conventional international trade; and

- to protect human rights by providing social justice, sound environmental practices and economic security.

Since its beginnings, the Fair Trade movement has expanded significantly and has become a multimillion-dollar enterprise, with the intention of returning a larger proportion of market price to Third World producers. In 2008, Harriet Lamb, the President of the Fairtrade Foundation, reported that there were 900 certified producer organisations in 58 developing countries. This represents over 1.5 million farmers and workers, and when their families are taken into account there are over 7.5 million people directly benefiting from Fairtrade (Lamb, 2008b). In 2010, the World Fair Trade Organization (WFTO) suggested that women make up more than 60 percent of those involved in Fair Trade. The WFTO echo the principles of FINE which make specific reference to promoting opportunities for women, arguing that through Fair Trade:

Women have the opportunity to realise their full potential; rights are respected; they play a full part in their communities; they are encouraged to take leadership roles; they participate in decision making; they are paid fair wages for the work they do (WFTO, 2010).

While FINE stress the role that Fair Trade can play in protecting women from exploitative market processes, the WFTO go further by implicitly suggesting that women can benefit by gaining more control over decision making and can be empowered to challenge prevailing power relations which subordinate them. In short, the potential impact of Fair Trade on women's opportunities and experiences is not straightforward but reflects the complex interplay of development and gender more generally, an issue to which we now turn.

\section{Gender and development}

Since the 1970s, the issue of gender inequality within developing nations and development processes has permeated the policies of international institutions and
Women and

Fair Trade

279 
CPOIB 8,4

\section{0}

NGOs, in an attempt to remove inequalities and empower women. Boserup's (1974) study of women in agriculture in developing nations is generally considered to be the catalyst that highlighted the gendered nature of development processes and the role of women in economic development. She highlighted how gender is a basic factor in the division of labour and how colonialism and the penetration of capitalism into subsistence farming have had negative consequences for women. While the study has been heavily criticised for failing to provide adequate explanations for the subordination of women (Beneria and Sen, 1997), her work is seen as the first attempt to locate gender relations within the study of development processes. The work also served to highlight how gender is a basic factor in the division of labour, as well as emphasising the negative impact that colonialism and the penetration of capitalism into subsistence economies has had on women (Beneria and Sen, 1997). In essence, Boserup (1974) argues that women are marginalised in the process of economic development because their economic gain as wage earners, farmers, and traders are slight, compared to those of male workers.

The significance of empowerment is highlighted when the power relations in which women live their lives, are considered. Sen and Batliwala (2000, p. 21, emphasis in original) suggest that these power relations operate at four different levels:

(1) The household and the family (gender-biased divisions or resources and labour: biased access to health, and/or education; strictures on physical mobility; weak role in decision-making; perceptions of women's reproductive capacity and sexuality as family property over which women do not have control).

(2) The community/village (caste/race/class biases that are particularly oppressive of women's social beliefs, norms, and practices that are biased against women's reproductive and sexual autonomy).

(3) The market (segmented and gender-discriminatory markets for land, labour, credit, technology, or other resources).

(4) The state (discriminatory legal systems or practices, poorly funded or poor quality government programmes and health services).

Given the interconnectedness of these levels, empowerment has to address each level, so that gains in one area can be consolidated by the other levels.

The rhetoric on empowerment is pervasive throughout academic writing and policy documents, but the concept is difficult to define. At its simplest level, empowerment can be defined as the "ability to make choices" (Kabeer, 2005) although this needs to be qualified. In order to be empowered real choices must be available; there must be alternative courses of action which exist and which are seen to exist (Kabeer, 2005). This definition reflects the approach of Third World Feminists of the 1970s and 1980s who used the concept of empowerment to consider gender differences that exist in the control and distribution of resources (Datta and Kornberg, 2002). Given that poverty and disempowerment go hand-in-hand (Kabeer, 2005), control over resources is fundamental to empowerment. In this sense, power is seen in a relational context stressing "power over" (Hartsock, 1985) however, more recently, the concept of "power to" has been considered more useful when defining women's empowerment. Datta and Kornberg (2002) suggest that "power to" relates to strategies of change, which women themselves can achieve, and which can increase their control over resources and 
generate decision making capacity. In a similar vein, Batliwala (1994, cited in Datta and Kornberg, 2002, p. 4) suggests that power can be defined as "control over material assets, intellectual resources, and ideology" whereas empowerment can be considered as "the process of challenging existing power relations and of gaining greater control over the sources of power".

Implicit within these definitions is the concept of self-reliance as outlined above, and the ability of women to make strategic choices in their own favour. Empowerment, therefore, is a process by which women gain more control over their own lives, and is based on both greater extrinsic control and an expanded sense of intrinsic capability and confidence to take control over one's circumstances (Sen and Baliwala, 2000). Such an approach became popular in the 1990s with a focus on the strategic needs of women being identified by women themselves (de Waal, 2006) and which signifies a move away from seeing women simply as victims, and a move away from the status of women towards the empowerment of women. Status carries with it connotations of levels within a hierarchy while empowerment implies the relationships which exist among the different levels of the hierarchy and which in turn impact on the status of women (Sen and Baliwala, 2000). Given these different definitions and implications of empowerment, the concept can be viewed as both a "process" and an "outcome" in gender relations, and therefore assessing the impact of Fair Trade programmes on women should encompass analysis of the processes of new trade relations and their subsequent impact on status. Further, we should also be aware that empowerment, as a concept, is rooted in Western notions of individualism and personal achievement (Datta and Kornberg, 2002) and we should not consider the transfer of its application to other cultures as unproblematic.

Empowerment can also be considered at different levels of analysis. The gender and development $(\mathrm{GAD})$ perspective, which attempts to consider women beyond merely their productive capacity, places gender relations central to any study or discussion of women and development (Beetham and Demetriades, 2007). The GAD framework goes beyond market-based explanations for the subordination of women and recognises that:

[...] gendered subordination is constructed at many levels and through many institutions, including the household, the community, and the state. The [GAD] approach also marked a shift from the efficiency approach's focus on "practical gender needs", which do not challenge gender roles and norms and are centred around immediate concerns (often inadequacies in living conditions), to encompass "strategic gender interests"... This marked a shift in both research and policy, from seeing women as beneficiaries whose lives could be improved without altering traditional gender roles, to viewing women as agents who can be empowered to improve their position in society (Connelly et al., 2000) [reference in original text] (Beetham and Demetriades, 2007, pp. 201-202).

As the above quotation suggests, the GAD framework is an attempt to reconcile cultural differences with global structures of inequality, and any analysis of the effects of Fair Trade on women must consider all of the levels outlined above.

There is a need to assess the impact of trade on gender equality and whether the costs and benefits of trade either empower women or indeed deepen existing inequalities (UNCTAD, 2004). Given that there has historically been a negative view of the contribution that trade can make to development, particularly in commodity markets (Bliss, 2007; Coote, 1992; Madely, 2000; Oxley, 1990) it is likely that women have been among the most adversely affected by such free trade processes. As a result

\section{Women and Fair Trade}

281 


\section{CPOIB}

8,4

\section{2}

Table I.

Studies which assess the impact and benefits of Fair Trade more agencies are conscious of considering trade from a gender perspective, although the impact of Fair Trade on gender relations in producer communities remains largely unexplored. In the following section we bring together some of the research that has been conducted, in order to explore the impact of Fair Trade on women.

\section{The impact of Fair Trade}

The evidence presented next is based on studies that evaluate the impacts and benefits of Fair Trade. The studies used are listed in Tables I and II. Table I lists those studies which have been carried out into the benefits or otherwise of Fair Trade, looking at different producer groups, while Table II lists those studies which focus on particular commodities. The studies referenced in the tables go beyond simply considering the economic benefits of Fair Trade, and also consider the indirect impact that Fair Trade has on families and wider communities, including benefits or otherwise for women. However, as we will demonstrate, the methodological approaches of such studies and the potential influence of vested interests in certain findings cast doubt on the generalisability of the results and suggest further research is required before we can draw confident conclusions about the impact of Fair Trade.

In 2007 the Fairtrade Foundation reported that independent academic studies, as well as anecdotal evidence, suggested that Fair Trade was having a positive developmental impact on farmers, workers and their families as well as the wider communities of these participants. In particular the report suggests that Fair Trade has lead to enhanced levels of "organisational democracy and transparency and personal

\begin{tabular}{ll}
\hline Author and publication date & Focus of the study \\
\hline Fairtrade Foundation (2007) & Fair Trade and development \\
Groos (1999) & Fair Trade, development and the Law \\
Lamb (2008b) & Fair Trade and development \\
Mayoux (2000) & Impact assessment of Fair Trade \\
Mayoux and Williams (2001) & Case study of Oxfam and Fair Trade \\
Murray et al. (2003) & Fair Trade and poverty alleviation \\
Nicholls and Opal (2005) & Fair Trade and ethical consumption \\
Oxford Policy Management (2000) & Impact assessment of Fair Trade \\
Raynolds et al. (2007) & Fair Trade and Globalization \\
Redfern and Snedker (2002) & Experiences of small enterprises involved in Fair Trade \\
\end{tabular}

\section{Table II.}

Studies which focus on Fair Trade in particular commodities

\begin{tabular}{ll}
\hline Author(s) and publication date & Commodity \\
\hline Blowfield and Gallet (2000) & Bananas \\
Lamb (2008a) & Bananas \\
Greig (2006) & Shea butter \\
Brind (2007) & Flowers \\
Eshuis and Harmsen (2003) & Coffee \\
Mayoux (2000) & Coffee \\
Murray et al. (2003) & Coffee \\
Ronchi (2002) & Coffee \\
Tallontire (2000) & Coffee
\end{tabular}


participation and empowerment" (Fairtrade Foundation, 2007). This is corroborated by a report which argues that one of the most important impacts of Fair Trade initiatives lies in strengthening the capacity of producer organisations and increases their bargaining power, thus suggesting that Fair Trade initiatives are key vehicles for empowerment (Oxford Policy Management, 2000). To arrive at a judgement as to whether these assertions are valid in relation to women's empowerment, we review the evidence contained in recent research, paying particular attention to the methodological bases of the research and focussing on the reported impacts for producers, communities, families and women.

\subsection{Impact for producer organisations}

The basic tenets of Fair Trade place a great emphasis on the benefits accruing to producer organisations through attempts to rebalance the power relations between producer and First World consumer organisations. Producer organisations usually refer to the co-operatives and other representative organisations formed by farmers or employees involved in Fair Trade production. The benefits are usually seen in economic terms and include better bargaining positions, better credit worthiness and economies of scale with the system contributing to organisational successes through capacity building, the initial guaranteed market, improved linkages with the international market and by learning-by-doing in exporting (Lamb, 2008b). Aranda and Morales (2002, cited in Murray et al., 2003) suggest that Fair Trade lends certain kudos to producer organisations, stemming from external monitoring and the guaranteed standards that Fair Trade labelling provides.

For example, Ronchi (2002) suggests that producer involvement in the Coocafé co-operative has allowed for more confidence in investment decisions, amongst people who are traditionally risk averse because of the poverty they experience. The security and confidence developed through involvement in the coffee co-operatives has underpinned a number of long-term investments, an example of which is the purchase of farmland for distribution to the children of co-op members, in an attempt to stem the rural-urban flow. However, as Nicholls and Opal (2005) suggest, the success of such a scheme may be limited as urbanisation processes continue to attract younger people away from rural farming into cities. Further, the case study methodology employed in this research limits the generalisability of the results, and we are only able to infer the potential benefits to women involved in such initiatives.

\subsection{The impact on producers and their families}

Beyond the economic impact of Fair Trade, Redfern and Snedker (2002) identify the empowerment of producers as one of the key goals of initiatives, suggesting that this is achieved in number of different ways. This might mean ownership of the means of production at one end of the scale, and some degree of representation and more democratic arrangements for employment, though not necessarily control, at the other. The position of producers and farmers is said to be greatly enhanced by the provision of guaranteed fair prices and the provision of the social premium that they receive. Higher incomes and the stability of prices have an obvious direct economic impact, which may then, in turn, create social benefits for producer's families. Among the benefits of an enhanced economic situation identified for coffee growers in Costa Rica are: improved stability and security; electricity in the homes of producers and other

\section{Women and Fair Trade}

283 
CPOIB 8,4

284 home improvements; the payment of long standing debts; prolonged periods of education for children; and the purchase of cars to transport coffee seeds to markets (Ronchi, 2002). Other research shows that Bolivian coffee producers can send their children to school, buy better food and clothes, improve housing and install electricity (Lamb, 2008b).

The ability to participate in education is a commonly reported positive consequence of involvement with Fair Trade. This participation is facilitated in a number of ways. Lyon (2002, cited in Nicholls and Opal, 2005) found that the higher income generated through involvement in Fair Trade allowed farmers to pay workers to work on farms, thus freeing children from labouring, and giving them the time to attend school. Other studies have indicated how the Fair Trade premium has allowed the funding of various projects to make education more accessible for the families of producers. Ronchi (2002) highlights three projects funded by the Coocafé co-operative in Costa Rica: the Educational Extension Fund which provides materials, equipment and other resources for marginalised rural schools; secondary school scholarships which provide funding for pupils to buy books, uniforms and even shoes; and the University scholarship, the application process of which actively attempts to encourage female participation rates in higher education.

The ability to educate children is highly regarded among Fair Trade beneficiaries (Nicholls and Opal, 2005). This can be demonstrated by the example of women cotton farmers in the Dougoroukoroni co-operative in Mali, who spent their first social premium on the construction of a schoolhouse, which, after opening, was filled with children wanting an education (Lamb, 2008b). Given that there exists a positive correlation between education and development (Porritt, 2007), it can be argued that Fair Trade will have a direct impact on educational attainment and will be a positive developmental force for producers and their families. However, we cannot surmise from such cases that the benefits of education would be enjoyed equally by both sexes, and we need to bear in mind the possible exclusion of girls and women from educational opportunities in some communities.

As well as education, it is reported that Fair Trade has led to the development of a range of peripheral services, which benefit producers and their families. Improved health and nutrition is facilitated through a number of projects. In Malawi, Fair Trade peanut farming has provided funds for the sinking of more boreholes, which provide safer, cleaner water thus reducing diseases (Van Vark, 2008). Improved access to food through participation in organic gardening and subsistence supply projects has benefited the coffee growers in Latin America (Murray et al., 2003). These producers also benefit from the existence of a credit programme which helps pay for a variety of family emergencies.

The emergence of social and infrastructure networks as highlighted in the foregoing examples demonstrates a number of things. First, trade under conditions which put the producer rather than the market at the centre of the process has both direct (through increased prices and incomes) and indirect impacts for producers and their families. Second, the indirect impacts appear to improve the wellbeing of families in some developing nations providing dignity and increased self-esteem for producers, as well as improving their future prospects. Indeed, increased self-esteem is often reported as an indirect and less tangible positive impact of Fair Trade. As Murray et al. (2003, p. 8) report:

Farmers' sense of their importance within their communities is often undermined by the increasing degradation of traditional lifestyles and the growth of rural poverty in Latin 
America. But in case after case, farmers reported that increased attention to their farming including visits of Fair Trade and organic inspectors, buyers and even visiting Northern consumers (see for example Mendez, 2002; Lyon, 2002; references in original text) - promoted renewed pride in coffee farming.

\subsection{Impact for communities}

Many of the examples listed in the previous two sections have direct and indirect impacts for communities. The reports of investment of the Fair Trade social premium in education and training represent a significant development for the human capital of the communities involved. The Fair Trade premium allows for investment in schools, hospitals and clinics and in environmental projects. It is argued that such projects "contribute directly to local, national and global efforts to meet the United Nation's Millennium Development Goals (MDGs) in health, education and environmental sustainability" (Fairtrade Foundation, 2007). It would appear that the bottom-up approach to development has provided some movement towards the attainment of the MDGs. Murray et al. (2003) report that the guaranteed prices and the payment of the Fair Trade premium have allowed communities to become more self-sufficient and empowered with positive impacts on health and security. Access to fresh water and basics such as electricity and sanitation has improved the quality of life for many producers and their families. In Oaxaca, the Union of Indigenous Communities in the Isthmus Region (UCIRI) co-operative have used the social premium to build latrines, purchase fuel efficient household stoves, help reduce disease and smoke related respiratory problems and fund projects to reduce deforestation. Higher incomes have also spawned other businesses in the community such as a pharmacy and a bakery (Murray et al., 2003).

The review of the impact of Fair Trade presented above represents, on the whole, an extremely positive image of the impact of Fair Trade on producers and their communities. This is hardly surprising given that many of the impact studies have been carried out by individuals or organisations, or on behalf of organisations, with a vested interest in the Fair Trade movement (Fairtrade Foundation, 2007; Lamb, 2008a; Eshuis and Harmsen, 2003; Mayoux and Williams, 2001; Oxford Policy Management, 2000). Also the methodological approaches taken tend to limit how far we can take the findings as representative of Fair Trade initiatives in general. It is difficult to envisage how this situation could be improved given the practical problems of researching a phenomenon globally, but in the meantime we need to guard against seeing such results as being a ringing endorsement of Fair Trade. Further, whilst we might assume that community benefits will be enjoyed by all members of that community, this could be a dangerous assumption in cultures where there are deep-rooted gender inequalities. Thus, inferring that women are benefiting from Fair Trade on the basis of these studies is risky. In the following section we examine further evidence about the experience of women involved in Fair Trade, and the impact that the movement has had on gender relations in producer communities.

\section{Women and fair trade}

As mentioned earlier, the development of opportunities for women is one of the underlying principles for the Fair Trade movement. Fair Trade organisations include respect for women in their criteria and aim: to recognise the work of women; to secure

\section{Women and Fair Trade}


CPOIB 8,4

\section{6}

their employment; to improve income levels; and to ensure access to technology, credit and the decision making process (Redfern and Snedker, 2002). It is further suggested that empowering women means addressing the inequalities they experience in their own communities. As Redfern and Snedker (2002, p. 38) suggest:

Women work longer hours than men in every country in the world, yet their contributions at home and at the workplace are often invisible. Women are under represented and underpaid. Women comprise two thirds of the world's poor. As Fair Trade seeks to tackle poverty then it is necessary to identify and target women.

A number of the studies referred to above report on the impact that Fair Trade has had on the lives of women and gender relations in participating communities, identifying both direct and indirect effects on the livelihoods and experiences of women. More specifically focussed studies have examined gender relations in the context of Fair Trade and considered the extent to which these issues have been addressed. Women's involvement in Fair Trade is considerable. Oxfam have suggested that more than eighty per cent of the 100,000 people involved in the production of Fair Trade handicrafts in Bangladesh are women (Redfern and Snedker, 2002). Women are directly involved in coffee farming (Eshuis and Harmsen, 2003; Murray et al., 2003; Mayoux, 2000; Tallontire, 2000), shea butter production (Greig, 2006; Harsch, 2001) banana cultivation (Blowfield and Gallet, 2000), handicrafts (Mayoux and Williams, 2001), peanut growing (Van Vark, 2008) and horticulture (Brind, 2007; Tallontire et al., 2005). As more and more products are certified as Fair Trade the number of women involved is likely to increase.

The analysis above suggests that the most obvious economic benefit of involvement in Fair Trade is increased income through the payment of a "fair price" and other disbursements of the Fair Trade premium. This increase in income is significant for women. For women in India, craft production provides a route to paid employment when few such opportunities exist and this production can take place at home which allows the women involved to fit paid work around domestic work and any other agricultural work in which they are involved (Redfern and Snedker, 2002). For many women this provides a valuable source of income, particularly when the fact that the women who are involved in such handicraft production are often single heads of households, with multiple responsibilities. As indicated previously, women often fulfil a productive role, but this is usually combined with the burden of other responsibilities such as domestic work and tasks within the community (Beneria and Sen, 1997; Moser, 1993; Poalisso and Leslie, 1994). Increased income from Fair Trade can ease some of the burden of multiple responsibilities. Female peanut farmers in Malawi have responsibility for caring for children and the elderly, domestic work, and fetching water when there is often not a safe supply (Van Vark, 2008). Fair Trade has alleviated some of these pressures as fair prices provide greater security and the Fair Trade premium has funded investment which frees women from some unpaid labour and enables them to be more productive. For example, the development of a clean water supply within communities has freed up time that would have been spent collecting water.

Shea butter (a product which is used in cosmetic production) provides an income for women in Burkino Faso (Greig, 2006). Shea nut harvesting and butter production is unusual in that it is the sole preserve of women. The location and harvesting techniques are known by Burkinabè women, who pass on the skills and knowledge regarding shea 
nut harvest through generations. Efforts to cultivate the trees have been unsuccessful so knowledge of the location of the trees is a valuable resource for women, and the production of the oil or butter from the nuts offers a unique opportunity for Burkinabè women to generate income in their own right, and affords women respect, authority and control over resources that they would not otherwise enjoy (Greig, 2006; Harsch, 2001).

The above examples suggest that Fair Trade can offer economic resources to women, but there is also evidence that increased income can afford women more control in households as well as over their own future, as the two quotations below suggest:

I think I have some voice in our family decisions since I earn something for my family.

And

[...] unmarried girls, are considered [in the region] a big expense burden on the family. Women are now seen as contributing to their families, a little exposure has given women courage to overcome their fear of men (Mayoux and Williams, 2001).

It is clear that, in some instances, increased access to economic resources has the knock-on effect of increasing confidence and self-esteem among some women.

Shea nut production and handicraft production are areas in which women have traditionally been the main producers. To assess the general impact of Fair Trade on women we also need to consider those areas that have traditionally been controlled by men, such as banana and coffee farming (Blowfield and Gallet, 2000; Tallontire, 2000). In the case of banana cultivation, plantation work is gender-specific, with men considering fieldwork such as harvesting, clearing and replanting, as an extension of farming responsibilities. While Fair Trade banana cultivation has increased livelihood opportunities, evidence suggests that women have been less likely to benefit in this context. Blowfield and Gallet (2000) found that only 16 per cent of workers in Volta River Estate banana production in Ghana were women, with the gender imbalance being blamed on the nature of the work. The report also suggested that selection criteria for involvement in projects associated with Fair Trade banana production might be biased in favour of men. One of the criteria for involvement is that a participant's family have four adult members to work in the plantation, however, experience elsewhere in Ghana suggests that female-headed households are less likely to have access to family labour. In this sense, women do have equality of access to opportunity but because of the nature of the selection criteria, and the gendered nature of production, they are less likely to participate in projects (Blowfield and Gallet, 2000) and are therefore less likely to benefit from them.

Coffee farmers in the Kilimanjaro Native Co-operative Union (KNCU) which supplies coffee to Cafédirect, the UK's biggest Fair Trade hot drinks company, are predominantly men which can be seen as a direct result of land ownership being a condition of membership. Although female labour is vital to coffee cultivation and harvest, their interests are not represented within the co-operative (Tallontire, 2000). Tallontire goes on to argue that this gender imbalance has not been challenged by KNCU or Twin[2] who are the partners in the Fair Trade Relationship. Women's involvement in commercial cocoa production is also circumscribed by issues to do with land ownership and gender stereotypes, even where affirmative measures have been put in place to encourage the active and effective participation of women in decision

\section{Women and Fair Trade}


CPOIB 8,4 making. Madely (2000)2 review of the activities of the Kuapa Kokoo Farmer's Union (KKFU) in Ghana outlines some of the measures that have been put in place to encourage the involvement of women. These measures are centred around ensuring that there are a number of women representatives on committees such as the regional council, the National Executive Committee the KKFU Board and the Board of trustees. Such affirmative measures would suggest that women are represented in the KKFU, however Mayoux's review indicates that access to these positions is highly dependent on access to land for cocoa production. As she suggests:

Women are involved in all aspects of cocoa production and primary processing: though cocoa as a cash crop is viewed as a man's crop largely because of the land ownership structure [which exists]. Even where women have access to their own land, their farm size is smaller because of a combination of factors: limited capital base, obligations to work on their husband's farm and more off farm workload. This lack of access to land, as well as gender stereotypes and divisions of labour also affects the types of other activities in which women can engage. In particular it is difficult for them to plant permanent tree crops (Mayoux, 2000).

This is not an isolated case. In developing countries, women's access to land and credit is even more limited than that of men because of social, cultural and political factors (Datta and Kornberg, 2002; UNCTAD, 2004). Furthermore, within smallholder farming, family labour may not be factored into costs of production resulting in women not receiving direct remuneration for the work carried out. Fair Trade encourages export crop cultivation where earnings are often controlled by men, despite the vital role that women play in production of commodities such as coffee and cocoa. The net result may be that women are not financially rewarded for the work that they do, while at the same time family farm obligations and land ownership restrictions prevent them from managing farms of their own, or having control over income (Redfern and Snedker, 2002). Even in the example of shea butter production, which is the preserve of women, such activity is confined to the informal sector. Traditional gender relations in which men control formal commodity production restrict women to small-scale subsistence production and the local market (Greig, 2006). Moreover, if a Burkinabé woman's husband does not approve of his wife's involvement in commercial activity he may prevent her from taking part (Saul, 1989 cited in Greig, 2006). Nicholls and Opal (2005) consider that women's participation in commercial agricultural production is a mixed blessing, in that women may be rewarded for their involvement, but this often leads to an overall increase in workload as productive activity does not exempt them from domestic responsibilities and other tasks within the local community.

The sexual division of labour highlighted in these examples is fairly typical of gender relations in various parts of the developing world. Men are more likely to be employed in more highly skilled, core areas of production while women are often employed in lower paid, lower skilled jobs:

At Bahay, in the Philippines, men are usually working with machines but women are employed in the lower skilled manual jobs of sanding, finishing and assembly, which require careful attention to detail. There are equal wages for the same work but as only men run the machines, they receive higher wages (Mayoux and Williams, 2001).

Also, it is typical for the burden of domestic responsibility to fall on women:

To all intents and purposes, gender relations within the household remain traditional. Respondents either expressed the view that the man was necessarily the head of the family or 
if they said it was joint and consultative leadership, he was the ultimate decision maker. In addition, chores within the household were divided in the traditional manner, with wives and female children doing the bulk of the chores. There were a few exceptional cases, where relations were more egalitarian and also a few exceptional cases where views expressed were outright chauvinistic or family relations clearly oppressive (Philippines) (Mayoux and Williams, 2001).

The evidence seems to point towards involvement with Fair Trade having limited impact on traditional gender relations in developing nations. Research suggests that there is no challenge to gender segmentation, and that female stereotypes may have been reinforced as in the case of the Kula-a craft case study in West Bengal (Das, 2009).

One of the most significant ways in which Fair Trade impacts upon the lives of women is through the payment of and the distribution of the Fair Trade social premium. It has already been indicated that this premium is often used for community projects. Women producers in receipt of this premium are able to decide who benefits from this, and to which projects the premium will contribute. As already mentioned, the women cotton farmers in the Dougoroukoroni co-operative in Mali spent their first Fair Trade premium on building a school. This prompted a jointly-funded project between the local government and the co-operative to increase the size of the original school which was overwhelmed by the number of pupils attending (Lamb, 2008a). Lamb's report also highlights the example of the UCIRI co-operative in Oaxaca in Mexico, which used the premium to create a training centre for women's literacy. The case of the female peanut farmers outlined above also highlights that investment in local water projects has helped women by providing a safe and clean supply of water, leading to a reduction in diseases having a positive impact of health.

In a study of Kenyan flower farms, Brind (2007) suggests that the social premium paid to farmers has had a significant impact on community participation rates, and has improved the livelihoods of workers. Proportional representation in the representative system for decision making regarding the premium, meant that women were represented, which had a direct empowering effect on them. Women have been actively encouraged for standing for election onto representative boards. Brind (2007) argues that Masai men and women were adamant that the whole of the community was involved in identifying project needs, but that wider power relations in the community were likely to be apparent in the decision making groups. For example, women were usually excluded from group meetings as they were not allowed to speak in front of the men, suggesting that women's involvement in decision making is strictly controlled by the cultural power relations that exist in such communities.

\section{Conclusion}

Appraising the effects of Fair Trade on women is difficult, and the available research on the issue must be approached with caution. It is not possible to generalise about women's involvement in, and experiences of Fair Trade, because the evidence available tends to be limited. Most of the studies cited above are based on specific case studies of particular programmes and they are characterised by particular local cultural conditions. Whilst we can be sure that the research accurately reflects experience in those cases we cannot extrapolate from them to other contexts. As we have seen some forms of production offer greater opportunities for women than others, because of the prevailing cultural and economic features of certain communities, so, for example, the

\section{Women and Fair Trade}

289 
CPOIB

8,4

290 positive outcomes in shea butter production cannot be assumed to be found in the coffee production context. Indeed, we cannot be sure that one case of shea butter production necessarily reflects the experiences in other cases. In the absence of a large-scale survey of experiences, which would be fraught with methodological difficulties, we can only watch the slow accumulation of case evidence in the hope that patterns and general trends may emerge. This reiterates the findings of Nelson and Pound (2009) who suggests that there is little evidence on which to base an assessment of whether Fair Trade challenges gender norms and empowers women. Moreover, they suggest that further research is required to understand the gender-differentiated impacts of Fair Trade to avoid the risk of entrenching gender inequalities even further.

An additional problem lies in the vested interests that are attached to Fair Trade initiatives. In general, academic researchers tend to be suspicious of research sponsored or organised by corporations because there is always doubt that vested interests shape the findings of such research. Some of the research we have considered in this paper comes from groups or organisations that have vested interests in Fair Trade so, as with corporations, we should be wary of those interests colouring the findings. As Fair Trade is inevitably seen as "a good thing" it may be difficult for researchers to acknowledge the inadequacies or limitations of the programmes they examine. For instance, examples are given in many studies of how the Fair Trade premium is invested for the benefit of communities, however one might ask whether there are other cases where the premium is not used in this positive and productive way. Parallels can be drawn with criticisms raised by Griffiths (2010) who argues that advocates of Fair Trade rely upon anecdotal and case evidence to demonstrate the positive impact of Fair Trade. This, he suggests, does not provide an unbiased view of the experience of those involved in Fair Trade production and that we need to be open to the possibility that the benefits to producers may be overstated and not equitably distributed.

More specifically in relation to gender and Fair Trade, there is a dearth of sound research and little that addresses different levels of change that the GAD perspective suggests is necessary to fully understand the impact of development efforts on women. The findings, such as they are, suggest that the impact of Fair Trade is dependent on existing local arrangements such as the sexual division of labour, patriarchal attitudes and the ability of women to own and control the means of production. Fair Trade does not seem to have led to "challenging existing power relations, and gaining greater control over the sources of power" (Batliwala, 1994: cited in Datta and Kornberg, 2002, p. 4). Indeed, Fair Trade practices themselves can be considered gendered as they largely fail to challenge the prevailing power relations in communities.

Future research on woman and Fair Trade needs to nest an assessment of Fair Trade processes and outcomes within the community and cultural context as the GAD perspective would suggest. This of course makes comparisons across differing contexts difficult. However, one mode of comparison that could be made is between Fair Trade and non-Fair Trade operations in the same context, allowing a comparison of women's experiences that would better reveal the impact of Fair Trade. Also assessments should provide more background information about communities and cultures so that the results are properly contextualised. Finally, the research should demonstrate some reflexivity, with researchers questioning whether Western benchmarks of gender relations are necessarily transferable or even welcome 
amongst women in other cultures. This highlights the need for clearly defined terms of reference in such research, which do not rely upon Western definitions of empowerment but instead reflect the complex interplay between gender, patriarchy and the social relations of production experienced by women involved in Fair Trade.

\section{Notes}

1. FINE is an acronym made up from the initial letters of the umbrella organisations which it encompasses - Fairtrade Labelling Organizations (FLO International), International Federation for Alternative Trade (IFAT), Network of European World Shops (NEWS!) and European Fair Trade Association (EFTA).

2. TWIN is a producer owned membership organisation which develops Fair Trade supply chains for coffee, nuts, cocoa, sugar and fruit farmers.

\section{References}

Aranda, J. and Morales, C. (2002), "Poverty alleviation through participation in fair trade coffee: the case of CEPO, Oaxaca, Mexico", Colorado State University, Fort Collins, CO, available at: www.colostate.edu/Depts/Sociology/FairTradeResearchGroup

Batliwala, S. (1994), "The meaning of women's empowerment: new concepts for action", in Sen, G. (Ed.), Population Policies Reconsidered: Health Empowerment and Rights, Harvard University Press, Cambridge, MA.

Beetham, G. and Demetriades, J. (2007), "Feminist research methodologies and development: overview and practical applications", Gender and Development, Vol. 15 No. 2, pp. 199-216.

Beneria, L. and Sen, G. (1997), "Accumulation, reproduction and women's role in economic development: Boserup revisited”, in Visvanathan, N., Duggan, L., Nisonoff, N. and Wiegersma, N. (Eds), The Women, Gender and Development Reader, Zed Books, London, pp. $42-50$.

Bliss, C. (2007), Trade, Growth and Inequality, Oxford University Press, Oxford.

Blowfield, M. and Gallet, S. (2000), Ethical Trade and Sustainable Rural Livelihoods - Case Studies: Volta River Estates Fairtrade Bananas Case Study, Natural Resources Institute, University of Greenwich, London.

Boserup, E. (1974), Women's Role in Economic Development, Gower in association with London School of Economics, London.

Brind, T. (2007), "Who decides and who benefits? Fairtrade social premium investments on Kenyan flower farms", unpublished MSC dissertation, University of Birmingham, Birmingham, available at: www.idd.bham.ac.uk/research/dissertations/06-07/Brind.pdf (accessed 1 April 2009).

Coote, B. (1992), The Trade Trap: Poverty and the Global Commodity Market, Oxfam/Alden Press, Oxford.

Das, R. (2009), "Compromising social justice in fairtrade? Case study of a fairtrade organization in India", Working Paper No. 467, Institute of Social Studies, The Hague, available at: www.iss.nl

Datta, R. and Kornberg, J. (2002), "Introduction: empowerment and disempowerment”, in Datta, R. and Kornberg, J. (Eds), Women in Developing Countries, Lynne Rienner Publishers, London, pp. 1-10.

de Waal, A. (2006), "Evaluating gender mainstreaming in development projects", Development in Practice, Vol. 16 No. 2, pp. 209-14.

\section{Women and Fair Trade}




\section{CPOIB}

8,4

292
Eshuis, F. and Harmsen, J. (2003), Making Trade Work for the Producers: 15 Years of Fairtrade Labelled Coffee in The Netherlands, The Max Havelaar Foundation, Utrecht.

European Fair Trade Association (2006), "EFTA: joining Fair Trade jorces”, available at: www. European-Fair-Trade-Association.org/efta/doc.What.pdf (accessed 29 October 2011).

Fairtrade Foundation (2007), "International development committee inquiry into Fair Trade and development", available at: www.fairtrade.org.uk/includes/documents/cm_docs_2008/f/ fairtrade_foundation_idc_submission.pdf (accessed 22 February 2009).

Fridell, G. (2003), "Fair trade and the international moral economy: within and against the market”, CERLAC Working Paper Series, York University, Toronto.

Goodman, M.K. (2004), "Reading fair trade: political ecological imagery and the moral economy of fair trade foods", Political Geography, Vol. 23 No. 7, pp. 891-915.

Greig, D. (2006), "Shea butter: connecting rural Burkinabè women to international markets through fair trade", Development in Practice, Vol. 16 No. 5, pp. 465-75.

Griffiths, P. (2010), "Lack of rigour in defending fairtrade", Economic Affairs, Vol. 30 No. 2, pp. 45-9.

Groos, A.M. (1999), "International trade and development: exploring the impact of fair trade organizations in the global economy and the law", Texas International Law Journal, Vol. 34 No. 3, pp. 379-411.

Harsch, E. (2001), "Making trade work for poor women: villagers in Burkino Faso discover an opening in the global market", Africa Recovery, Vol. 15 No. 4, pp. 6-11.

Hartsock, N. (1985), Money, Sex and Power: Towards a Feminist Historical Materialism, North Eastern University Press, Boston, MA.

Jaffee, D. (2007), Brewing Justice: Fair Trade Coffee, Sustainability, and Survival, University of California Press, Los Angeles, CA.

Kabeer, N. (2005), “Gender equality and women's empowerment”, Gender and Development, Vol. 13 No. 1, pp. 13-24.

Lamb, H. (2008a), Fighting the Banana Wars and Other Fairtrade Battles, Random House, Chatham.

Lamb, H. (2008b), "Fairtrade: working to make markets fair", Trade - What If? New Challenges in Export Development, World Export Development Forum, International Trade Centre, available at: http://s3.amazonaws.com/zanran_storage/www.intracen.org/ContentPages/ 12671071.pdf (accessed 31 March 2009).

Lyon, S. (2002), "Evaluation of the actual and potential benefits for the alleviation of poverty through the participation in fair trade coffee networks: Guatemalan case study", available at: www.colostate.edu/Depts/Socology/FairTradeResearchGroup

Madely, J. (2000), Hungry for Trade, Zed Books, London.

Mayoux, L. (2000), "Impact assessment of fair trade and ethical enterprise development", available at: www.sed.manchester.ac.uk/research/iarc/ediais/word-files/IAofFairTrade (accessed 31 March 2009).

Mayoux, L. and Williams, P. (2001), “Case study: Oxfam Fair Trade”, available at: www.oxfam. org.uk (accessed 25 August 2008).

Moore, G. (2004), “The Fairtrade movement: parameters, issues and future research”, Journal of Business Ethics, Vol. 53 Nos 1/2, pp. 73-86.

Moser, C.O.N. (1993), Gender Planning and Development: Theory, Practice and Training, Routledge, London. 
Murray, D., Raynolds, L.T. and Taylor, P.L. (2003), "One cup at a time: poverty alleviation and fair trade coffee in Latin America”, Fair Trade Research Group, Colorado State University, Fort Collins, CO, available at: http://welcome2.libarts.colostate.edu/centers/cfat/wpcontent/uploads/2009/09/One-Cup-at-a-Time.pdf (accessed 16 November 2008).

Murray, D.L. and Raynolds, L.T. (2007), "Globalization and its antinomies”, in Raynolds, L.T., Murray, D. and Wilkinson, J. (Eds), Fair Trade: The Challenges of Transforming Globalization, Routledge, London, pp. 3-14.

Nelson, V. and Pound, B. (2009), "The last ten years: a comprehensive review of the literature on the impact of Fairtrade", available at: www.fairtrade.org.uk/resources/natural-resources_ institute.aspx, (accessed 15 October 2011).

Nicholls, A. (2005), "Thriving in a hostile environment: fairtrade's role as a positive market mechanism for disadvantaged producers", available at: www.fairtrade.org.uk/includes/ documents/cm_docs/2008/a/alex_nichols.pdf (accessed 16 November 2008).

Nicholls, A. and Opal, C. (2005), Fair Trade: Market Driven Ethical Consumption, Sage Publications, London.

Oxford Policy Management (2000), "Fair trade: overview, impact, challenges: study to inform DFDI's support to fair trade", available at http:/portals.wi.wur.nl/files/docs/ppme/ ACF3C8C.pdf (accessed 17 February 2009).

Oxley, A. (1990), The Challenge of Free Trade, Harvester Wheatsheaf, London.

Poalisso, M. and Leslie, J. (1994), "Meeting the changing health needs of women in developing countries”, Social Science and Medicine, Vol. 40 No. 1, pp. 55-65.

Porritt, J. (2007), Capitalism as if the World Matters, Earthscan, London.

Raynolds, L.T., Murray, D. and Wilkinson, J. (2007), Fair Trade: The Challenges of Transforming Globalization, Routledge, London.

Redfern, A. and Snedker, P. (2002), "Creating market opportunities for smaller enterprises: experiences of the fair trade movement", SEED Working Paper No. 30, International Labour Organization, Geneva.

Renard, M.C. (2003), "Fair trade: quality, market conventions”, Journal of Rural Studies, Vol. 19 No. 1, pp. 87-96.

Renard, M.C. (2005), "Quality certification, regulation and power in fair trade”, Journal of Rural Studies, Vol. 21 No. 4, pp. 419-31.

Ronchi, L. (2002), "The impact of fair trade on producers and their organisations: a case study with Coocafé in Costa Rica”, PRUS Working Paper No. 11, Poverty Research Unit, University of Sussex, Brighton, available at: www.sussex.ac.uk/Units/PRU/wps/wp11.pdf (accessed 23 October 2008).

Saul, M. (1989), "Separateness and relation: autonomous income and negotiation among rural Bobo women", in Wilk, R. (Ed.), The Household Economy: Reconsidering the Domestic Mode of Production, Westview Press, Boulder, CO.

Sen, G. and Baliwala, S. (2000), "Empowering women for reproductive rights", in Presser, H.B. and Sen, G. (Eds), Women's Empowerment and Demographic Processes: Moving beyond Cairo, Oxford University Press, Oxford, pp. 16-36.

Tallontire, A. (2000), "Partnerships in fair trade: reflections from a case study of Cafédirect", Development in Practice, Vol. 10 No. 2, pp. 166-77.

Tallontire, A., Dolan, C., Smith, S. and Barrintos, S. (2005), "Reaching the marginalised? Gender value chains and ethical trade in African horticulture", Development in Practice, Vol. 15 Nos 3/4, pp. 559-71. 
CPOIB

8,4

294
United Nations Conference on Trade and Development (2004), Trade and Gender: Opportunities and Challenges for Developing Countries, United Nations, New York, NY.

Van Vark, C. (2008), "Winning hearts and minds", The Guardian, available at: http://society. guardian.co.uk/fairtradeforall/story/0,2260032,00.html (accessed 13 April 2009).

World Fair Trade Organization (2010), "Fair Trade women's work for development and equity", available at: www.wfto.com/index.php?option $=$ com_content\&task=view\&id $=1158 \&$ Itemid $=305$ (accessed 15 October 2011).

\section{About the authors}

Louise McArdle is a Principal Lecturer in Management and Leader of the Division of Strategy and Enterprise in Lancashire Business School, University of Central Lancashire, UK. She has previously researched work and organisation in the manufacturing sector and is currently researching identity in the trade union movement. Louise McArdle is the corresponding author and can be contacted at: Lmc-ardle@uclan.ac.uk

Pete Thomas is a Senior Lecturer in Strategic Management in Lancashire Business School, University of Central Lancashire, UK. He has a PhD in Technology Management. His current research uses critical discourse analysis to investigate strategic management practices, and he is also researching professionalisation processes in the health and education sectors.

To purchase reprints of this article please e-mail: reprints@emeraldinsight.com Or visit our web site for further details: www.emeraldinsight.com/reprints 